\title{
EMOTIONAL INTELLIGENCE AS A COMPONENT OF YOUNG SPECIALIST-PSYCHOLOGIST'S PSYCHOLOGICAL WELL-BEING
}

\author{
ЕМОЦІЙНИЙ ІНТЕЛЕКТ ЯК СКЛАДНИК ПСИХОЛОГІЧНОГО \\ БЛАГОПОЛУЧЧЯ МОЛОДОГО ФАХІВЦЯ-ПСИХОЛОГА
}

UDC 159.942

DOI https://doi.org/10.32843/2663-

5208.2020.13-2.3

\section{Vashchenko I.V.}

Doctor of Psychological Sciences,

Professor at the Department

of General Psychology

of the Faculty of Psychology

Taras Shevchenko National University

of Kyiv

Shykovets S.O.

Ph.D. Student in Psychology

of the Faculty of Psychology

Taras Shevchenko National University of Kyiv
The article analyzes the problem of emotional intelligence in the context of the psychological well-being of a young psychologist. It was found that modern scientists mainly consider the process of forming the readiness of psychologists for professional activity through the universality of its nature, mastery of professional and psychological tools and personal changes of future psychologists in the process of educational and professional activities. An in-depth interview was conducted to determine the components of the psychological well-being of future psychologists. In particular, first-year students of Mykola Gogol Nizhyn State University and 10th grade students of Nizhyn Lyceum at Mykola Gogol Nizhyn State University were offered psychodiagnostic tools to determine the components of psychological well-being and emotional intelligence. The study of students' readiness to study is considered taking into account the principles of the methodological level in the course of professional training in the Free Economic Zone as a means of increasing emotional intelligence. Prerequisites for the development of emotional intelligence, such as: biological, social, age, professional development. Biological conditions are revealed, which include features of the structure and development of the human body, heredity of emotional abilities, temperament and principles of personality training, internal contradictions in the period of self-awareness, mobility and plasticity of speech stereotype, flexibility of thinking, sequence of thinking changes. The professional and developmental conditions of the student's readiness for activity through such concepts as: emotionality, emotional stability and emotional potential of the personality are analyzed. According to the results of empirical research, a correlation was established between the level of emotional intelligence and the level of creativity. One of the tasks of our further research is to create and test a method for determining the signs of a high level of emotional intelligence and the influence of emotional intelligence on the development of professional reflection of personality.

Key words: emotional intelligence, emotionality, psychological well-being, emotional readiness, development of El, professional reflection.

у статті проаналізовано проблему емоційного інтелекту в контексті психологічного благополуччя молодого фрахівця-психолога. З'ясовано, що сучасні науковці здебільшого розглядають процес фрормування готовності психологів до профьесійної діяльності через універсальність його характеру, опанування профресійно-психологічним інструментарієм та особистісні зміни майбутніх психологів у процесі здійснення навчально-професійної діяльності. 3 метою з'ясування складників психологічного благополуччя майбутніх фрахівців-психологів застосовано глибинне інтерв'ю. Зокрема, студентам 1-го курсу Ніжинського державного університету імені Миколи Гоголя та учням 10-го класу Ніжинського ліцею при НДУ імені Миколи Гоголя було запропоновано психодіагностичний інструментарій для визначення складників психологічного благополуччя та емоційного інтелекту. Дослідження готовності студентів до навчання розглянуто з урахуванням принципів методичного рівня у ході фрахової підготовки у ЗВО як засобу підвищення емоційного інтелекту. Визначено передумови розвитку емоційного інтелекту, як-то: біологічні, соціальні, вікові, профресійно-розвивальні. Розкрито біологічні умови, до яких віднесено як особливості структури і розвитку організму людини, спадковість задатків емоційних здібностей, темпераменту, так і принципи навчання особистості, внутрішні суперечності у період становлення самосвідомості, рухливості та пластичності мовленнєвого стереотипу, гнучкості мислення, послідовності змін мислення. Проаналізовано професійно-розвивальні умови готовності студента до діяльності через такі поняття, як: емоційність, емоційна стійкість та емоційний потенціал особистості. За результатами емпіричного дослідження встановлена кореляція між рівнем емоційного інтелекту та рівнем креативності.

Одним із завдань подальших наших досліджень є створення та апробація методики визначення ознак високого рівня емоційного інтелекту та впливу емоційного інтелекту на розвиток профресійної рефрлексії особиcmocmi.

Ключові слова: емоційний інтелект, емоційність, психологічне благополуччя, емоційна готовність, розвиток El, профессійна ресрлексія.
Formulation of the problem. Studies of the development of emotional intelligence (EI) in the system of professional training of psychologists in Ukraine, in accordance with current legislation, require to determine the tasks in the preparation of future students of higher education.

Despite efforts to improve the specialist, there are always questions for students about self-knowledge, setting priorities in learning, forming readiness for learning, creating the preconditions for the development of El and forming a high level of emotional intelligence, which is the main prerequisite for successful professional activity in the future.

Analysis of recent research and publications. The study of one of the little-studied phenomena - emotional intelligence, and especially its role in the training of highly qualified psycholo- 
gists, is a very modern direction for the realization of cognitive, creative abilities of scientists. Interest in emotional intelligence (EI) arose in the early twentieth century due to the inability of classical $I Q$ tests (tests of $I Q$ ) to explain the characteristics of motivation and behavior of people. It has become traditional to understand emotional intelligence and emotional competence as a condition for successful personal activity and professional growth.

A high IQ shows only the ability to work with logic, but not with emotions. It was John Mayer, Peter Saloway and their colleague David Caruso who first formulated the concept of emotional intelligence and worked tirelessly to ensure that El gained scientific recognition. The concept of EI has become known even in the most remote corners of our planet. The concept of emotional intelligence was supported by D. Goleman, launching programs of "social and emotional learning" (abbreviated SEL). In many parts of the United States, even in entire states, SEL programs have become a mandatory part of the curriculum.

Another important source of scientific theories about El was Reuven Baron, thanks to whom the world saw the "Handbook of Emotional Intelligence". The concept of "emotional ability" was discussed in the book "Emotional Leadership: The Art of Managing People Based on Emotional Intelligence" co-authored by D. Goleman with Richard Boyatsis and Annie McKee. The concept of "emotional competence" was proposed by David McClelland, a psychologist at Harvard University.

Ukrainian scientists are also interested in the study of El. For example, T. Kyrylenko considers El as a certain set of individual abilities or traits that are responsible for the extent to which the impact of emotional phenomena will be constructive or destructive for human behavior [6].

The urgency of the problem of El development is quite clearly presented in the works of Ukrainian scientists E. Nosenko and N. Kovryga in theoretical, social and pedagogical aspects. They believe that now psychology is able to quite authoritatively answer complex questions about the emergence of emotions and possible forms of their conscious regulation. It is the psychologist who is able to help the individual to understand his internal emotional problems, to reveal his inner potential and, perhaps, his own hidden El, which in the future will provide an independent solution to a person's psychological problems.

Analysis of the personality of a practical psychologist in the process of professional activity was considered (G. Ball, O. Bondarenko, M. Boryshevsky, S. Maksymenko, V. Molyako, N. Povyakel, O. Sannikova, N. Chepeleva). Identifying the relationship between the components of $\mathrm{El}$ and leadership, management qualities (D. Gastello, D. Goulman, V. Yermakov, A. Mitlosh, A. Petrovskaya). One of the promising areas of El research is the field of education (E. Aronson, M. Manoilova).

Analysis of specific features of El implementation as a tool for improvement quality of psychologists allowed to form the principles, approaches and algorithms of the methodological level for use in the course of their professional training in higher education institutions as an ancillary area of practice-oriented training future psychologists [2].

The development of El problems is an essential component of the development of personality in the 21st century. The training of future psychologists in the modern world faces the problems of today, related to the further employment of the appropriate level in the conditions of robotics and computerization of production, the general dependence on virtual quasi-communication. The solution to this issue is associated with the development of El in the process of learning in higher education, which will allow the future psychologist to realize himself in the human-human system, to be ready to solve creative new tasks.

Formulating the goals of the article. The purpose and objectives of the study are to determine the main priorities for the development of emotional intelligence of future psychologists in higher education, based on the principles of methodological level of student training and prerequisites for the development of El, which further contributes to the professional reflection of psychologists.

Presentation of the main research material. Methods and methodology of the research. The article uses a system of methods of scientific research in psychology: analysis and sequential synthesis of information related to the problem of work, comparison, understanding, systematization, classification and inductive generalization of relevant to the topic and purpose of theoretical and practical data, as well as in-depth interviews, questionnaires, correlation method.

Personal attitude to self-knowledge in the universe can be found in the statements of the ancient Greek philosopher Aristotle, as well as the philosophical reflections of Rene Descartes, Benedict Spinoza, G. Leibniz, I. Kant; at the stage of empirical research - evolutionary-biological theory of Charles Darwin, associative theory of W. Wundt, theories of emotions by W. James, $\mathrm{K}$. Lange, theories of intelligence by $\mathrm{C}$. Spearman, L. Thurston in the further study of emotional processes in the works of L. Vygotsky, O. Leontiev, S. Rubinstein, O. Tikhomirov, M. Arnold, A. Ellis, S. Schechter, K. Izard.

The development of El while studying in a higher education institution is intended for the formation of an individual's moral values, social activity, civic position and responsibility, healthy lifestyle, ability to think freely and self-organize in modern conditions. The future professional psychologist, even before entering the school, formed 
a certain goal for future activities. Research conducted by A. Reanom, T. Andreeva, N. Moskovichova, $\mathrm{H}$. Kireeva among students of six faculties of the university, showed that the choice of specialties is determined by the conformity of the specialty to abilities and aptitudes, the possibility of creative work and self-expression, as well as the prestige of the university. The priority of these motives is noted at all faculties. In addition to these motives, students attributed their choice to the fact that professions are modern and prestigious (faculties of journalism, economics), that professions are useful to society (medical, psychological), at the Faculty of Mechanics and Mathematics 7\% of respondents called their choice random, while in other faculties, almost no one called the choice random.

A characteristic feature was that the attempt to choose a high-paying profession was not mentioned as a leading motive in any faculty. An interesting feature was that students of philosophical and psychological faculties called the leading motive - knowledge of themselves, the world around them, the learning process itself, i.e. a clear cognitive motive, and political philosophers - the leading motive called the prospects of the chosen profession in the future [6].

Emotional intelligence, as a means of improving the quality of psychologists, allowed to form the principles of the methodological level in the course of professional training in higher education:

The principle of gender mainstreaming. Rational purposeful male psychologists identify in the client's confession primarily the problem that manifests itself through various manifestations, and do not attach (empathetically) such great importance to emotions and feelings as female psychologists.

The principle of the psychologist's ability to focus his subconscious attention on the client's personality. Key factors in the emergence of subconscious attention: emotional tension during the perception of the object, novelty, significance for survival, association with basic needs.

The principle of "psychological processing of their own needs". The essence of this problem is that in the case of stopping the internal dialogue for the perception of the subconscious emotional flow as a way of engaging El during psychological counseling is an undesirable actualization of their own psychological problems of the psychologist.

The principle of "individual language of probabilistic symbolization". The correspondence between nonverbal signals and the content and intensity of psychological characteristics both to reflect the client and for the language of translation of signals of the psychologist.

The principle of "introduction of the El method in the scheme of implementation of standard psychotherapeutic techniques" during training in universities before and after the application of specific psychological techniques.
The principle of "system analysis of the configuration of the emotional-sensory sphere" of the client's personality. Determining the balance of emotions and feelings allows, within the study of the problem of emotional intelligence, to dynamically and situationally identify and form hypotheses about the internal mechanism of individual psychological disorders and client problems.

The principle of "determining the balance of traits, accentuations and potential pathologies" as an integrated multidimensional personal problem-solving strategy.

The principle of "compensation of gender strategies of the psychologist". A special perspective of this principle is the problem of contradiction of personal strategies, when a male psychologist works with a female client or a female psychologist with a male client.

The principle of "daily training of the model of implementation of psychological assistance techniques using El". The way to solve this problem is to introduce the technique of emotional intelligence into the fabric of everyday life of a psychologist in the form of a conscious short-term challenge to the state of altered perception in thecourseofcommunicationwitheachnewperson.

Thus, the proposed theoretical and empirical model of the processes of $\mathrm{El}$ in the structure oftheprofessionalactivityofapsychologistrequires systematic application of the proposed principles and approaches in the course of professional training of future specialists in psychology [3].

The objective prerequisites for the development of emotional intelligence in the period of training and education in higher education are: biological, social, age, professional development. Biological preconditions for the development of $\mathrm{El}$ are revealed in the theories and positions of I. Andreev, K. Brand, G. Gardner, V. Druzhinin, K. Izard, I. Keindel, A. Libin, O. Luria, E. Naumov, V. Rusalov.

On the basis of numerous researches I. Andreeva allocates and characterizes social preconditions of development of emotional intelligence: syntonicity in childhood; (syntony is understood as instinctive consonance with others, i.e. natural instinct); development of rationality as you grow older (L. Hell, D. Ziegler; M. Goffman); the level of development of self-awareness (K. Grebennikov); emotionally favorable relationships between parents (G. Craig, Helen Bee); parental education and family well-being (N. Newcomb, Maoki Taylor); gender features of education (G. Orme, G. Craig); androgyny (G. Craig, A. Alexandrov, N. Olifirovich, I. Gromova); locus of control (D. Rotter, W. Khartoum); religiosity (I. Andreeva).

Social preconditions promote the development of emotional intelligence or inhibit this process, depending on the social relationships in vertical communication and action (children and adults) and in horizontal communication (children and their peers). 


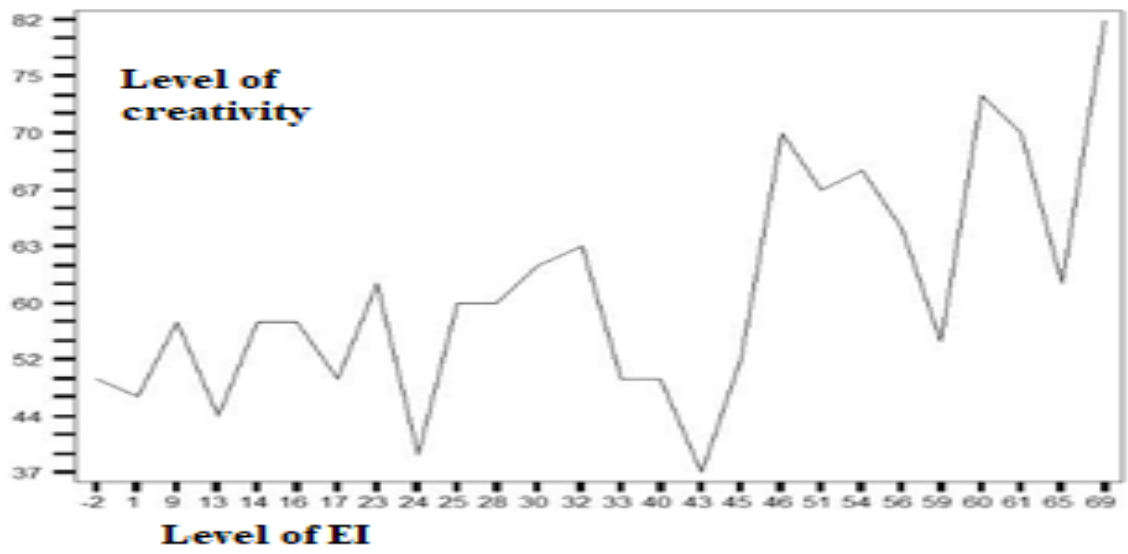

Fig. 1. Dependence of the level of creativity on the level of EI

Age-related features of the development of the ability to manage emotions also have a significant impact [4].

People in early adulthood try to choose a profession. In this regard, A.O. Rean introduces the concept of "professional self-concept of personality" as an idea of the individual about himself as a professional and identifies the real and ideal components.

Results and discussions. In our study 10 firstyear students-psychologists of Mykola Gogol Nizhyn State University and 10 10th grade students of Nizhyn Lyceum at Mykola Gogol Nizhyn State University were involved. The identified profiles of indicators of emotional readiness formed the basis for the allocation of three types of emotional readiness: moderate type, which corresponds to the first profile, sufficient type (second profile) and unfavorable type (third profile). Representatives of the moderate type are characterized by the following features: an average level of emotional intelligence, optimism and anxiety. Students who represent a sufficient type of emotional readiness show a high level of optimism, emotional intelligence and a low level of personal and situational anxiety. Representatives of the unfavorable type of emotional readiness for professional activity show a low level of empathy, the ability to recognize emotions, manage their emotions. Such tendencies are combined with high anxiety and a tendency to pessimism, which is characterized by instability of attributions, inability to control the events of his life.

The study found that the closest to optimal is the level of development of indicators of emotional readiness for professional activity in students of a sufficient type. At the same time, the study showed that the representatives of unfavorable and moderate types make up $59.2 \%$ of the sample, which proves the need for purposeful development of emotional readiness of future psychologists to work.

It is necessary to increase the level of El, especially in the senior classes of secondary school, while developing the level of creativity and expanding the range of interests of students. According to the results of the study on the development of emotional intelligence of students of Nizhyn Lyceum at Mykola Gogol Nizhyn State University (test for the study of emotional intelligence of Nicholas Hall), we can identify the following features of the development of emotional intelligence of students: $54.7 \%$ of students have low emotional intelligence; $45.3 \%$ have an average level of emotional intelligence.

There is no high level. After theoretical processing of the material on emotional intelligence, the indicators that are likely to affect El were also identified. Therefore, we determined the level of creativity of students (diagnosis of personal creativity E. Tunik), the level of mental intelligence (scale of progressive matrices of Raven, the average score and conducted a survey that identified the main hobbies of students. Using the following method of statistical processing data - Pearson's 2 criterion, a correlation analysis was performed between the given scales: emotional intelligence, creativity, mental intelligence and the average score of the score. The connection between emotional intelligence and creativity is graphically presented in the following graph (fig. 1).

\section{Dependence of students' enthusiasm on the level of EI}

Table 1

\begin{tabular}{|c|l|}
\hline Level of El & \multicolumn{1}{|c|}{ Hobbies } \\
\hline Medium & $\begin{array}{l}\text { Reading; Sports; Music; Drawing; Chess; Dances; Theatrical play; Video editing; } \\
\text { Computer games; Programming; Poetry; Writing; Mental arithmetic. }\end{array}$ \\
\hline Low & $\begin{array}{l}\text { Computer games; Sports; Drawing; } \\
\text { Music; Guitar; Cars; History. }\end{array}$ \\
\hline
\end{tabular}


With the development of emotional intelligence, the level of creativity of the student increases.

A survey of students' hobbies, which excludes subjects, identification of relationship between students' hobbies and their level of emotional intelligence, and a table of adolescent hobbies was compiled (table 1).

The results show the following: adolescents with an average level of emotional intelligence have a wider range of interests (chess, writing, mental arithmetic, video editing, dancing, etc.), more likely to read, less fond of computer games compared to their peers, who have a low level of El. Adolescents with low emotional intelligence most often referred to such hobbiesas computergames.

People with developed emotional intelligence find themselves capable in many areas, as well as with their help and develop their skills, which are part of emotional intelligence. Others, because the lack of these abilities causes numerous misunderstandings and conflicts between students, parents and other people. And this inhibits adaptive processes, reduces the value of learning and a positive attitude to the learning process, the desire to succeed in any endeavor. For a modern specialist it is extremely important to have a high enough level of development of emotional intelligence, which should be developed in the individual purposefully in the process of studying professionally important disciplines in preparation for professional activity. The importance of developing students' emotional intelligence in the process of their preparation for professional activity is due to the need to form in each of them the ability to reflect throughout their lives, to develop a critical attitude to training methods, which is always accompanied by certain emotional reactions.

The student is rethinking the essence of educational preparation for professional activity, which, of course, is accompanied by appropriate emotional and cognitive manifestations and testifies to the importance of emotional intelligence as an essential component of his professional activity. It is emotional-cognitive processes that allow individuals to objectively assess themselves, adequately respond to various life and professional situations, observe themselves in the world of their own feelings, internally differentiate "I who act", "I who think", "I who evaluates". Reflection is impossible without emotional intelligence and is manifested in the extent to which a person is aware of how he is perceived by a communication partner. It is not just an understanding of the other, but also a knowledge of how the other understands it, it is a double process of mirror reflection of communication partners. Due to this, it has a positive effect on the processes and results of thinking, regulates the activities and behavior of the subject. This mutual reflection of the subjects includes several positions that the subjects occupy in professional activities: the awareness of each subject of what he/she really is as a professional; how he/ she sees himself/herself in professional activities; how it is perceived by other actors in the process of professional activity.

Conclusions from the study and prospects for further research. The choice of a future specialty by a young person lies in the prestige of the future specialty, the definition of leading motives and principles of professional training for the functioning of emotional intelligence. The main feature of modern youth of Ukraine is not always an attempt to choose a high-paying profession, but to form themselves in such a way as to be useful to the State and people, for this we need specialists in psychology and other specialists with knowledge of psychology. These objective prerequisites for the development of emotional intelligence during training and education in higher education: biological, social, age, professional development. Prerequisites for the development of El to the emotional readiness of a student of higher education for professional activities were revealed through the understanding of such concepts as: emotionality, emotional stability and emotional potential of the individual.

Increasing the level of El is directly associated with the development of creativity, which is realized through hobbies, including the disciplines studied, to form a high level of El and professional reflection.

Prospects for further research are to determine effective means of forming emotional intelligence in higher education institutions with further orientation of graduates in the difficult conditions of today.

\section{REFERENCES:}

1. Ващенко І. В. Психологічні технології конструктивного самозбереження особистості в епоху суспільних транссрормацій. Розвиток особистості в різних умовах соціалізації : монографія. / Л. Калмикова, Л. Хомич (ред.). Київ : Слово, 2016. С. 405-421.

2. Ващенко І.В., Курмач Н.В. Емпіричні рефреренти емоційного інтелекту керівника. Матеріали $V$ міжнародної науково-практичної консреренції «Актуальні проблеми експериментальної психології: досвід та перспективи». Кам'янець-Подільський : ПП «Медобори-2006», 2019. С. 15-18.

3. Ващенко І.В., Онуфррієва Л.А. Сутнісні характеристики та структурні компоненти емоційної зрілості працівників комерційних банків. PSYCHOLOGICAL JOURNAL. № 5 (15), 2018. C. 224-236. DOI (Issue): https://doi.org/10.31108/1.2018.5.15.

4. Дерев'янко С.П. Феноменологія ЕІ : навчально-методичний посібник. Чернігів : Вид-во «Лозовий B.M.», 2016. 312 C.

5. Зарицька В.В. Теоретико-методологічні основи розвитку емоційного інтелекту в контексті професійної підготовки : монографрія. Запоріжжя : Вид-во КПУ, 2010. 304 c.

6. Кириленко Т.С. Психологія: емоційна ссрера особистості : навчальний посібник. Київ : Либідь, 2007. $256 \mathrm{c}$. 